\title{
WOORD EN WEDERGEBOORTE
}

I. Begripsbepaling.

a. Woord. Die uitdrukking "Woord van God" het verskillende betekenisse in die Heilige Skrif:

1. die krag van God waardeur Hy alle dinge skep en onderhou (Gen. I : 3; Ps. $33: 6$; Hebr. $1: 3$ ); 2 . die besondere openbaring waardeur God iets bekend maak (Jer. $7: 1 ; 10: 1)$; 3 . die inhoud van die openbaring (Ps. 33 : 4; Rom. $3: 2$ ); 4. die Evangelie deur die apostels verkondig (Joh. $17: 8$; Hand. $8: 25$ ) ; 5. die Skrif of 'n gedeelte daarvan (Ps. 119 : 105); 6. die naam vir Jesus Christus in Joh. 1.')

b. Wedergeboorte. 1. Ook hieroor spreek die Skrif in meerderlei sin:

(a) die herstelling van die skepping in sy oorspronklike volkomenheid (Matth. $19: 28$ ) - Vir ons onderwerp het dit nie direkte betekenis nie, behalwe dat dit wys op herstelling van die tans bestaande wat deur die sonde aangetas en geskend is;

(b) só dat die nadruk val op die beginsel van die nuwe lewe;

(c) of dan weer só dat dit meer sien op die ontplooiing en ontwikkeling van die nuwe lewe. ${ }^{2}$ )

2. Daar moet op gelet word dat Jesus in Joh. 3 spreek van geboorte van bo en opnuut (anoothen) en 1 Joh. 3 spreek van uit God gebore.

3. Wanneer ons spreek van weder-geboorte hou dit in dat na die eerste geboorte moet iets bykom of verander word. Natuurlik kom dit daarvan dat die mens deur die sonde aangetas en gedood is, sodat vernuwing noodsaaklik is. Naas die geboorte moet daar dus 'n tweede gebeurtenis volg - om in die koninkryk Gods te kom (Joh. 3).

4. In die natuurlike lewe is die geboorte 'n wonder van God. Hy gebruik daarby egter middele (mense), en dit is 'n gebeurtenis wat sy oorsprong in die ontvangenis het en dit is 'n proses met 'n tydsduur. Dit mag vir ons onderwerp van belang wees om dit in gedagte te hou.

5. Dit moet ook vermeld word dat 'n mens gebore word en nie aan homself geboorte skenk nie, en dit gebeur buite sy wil en bewussyn om, terwyl sy wil en bewussyn daarna begin funksioneer.

II. Die teks van ons Belydenisskrifte.

Voordat ons in die onderwerp afdaal, sal dit goed wees om eers te hoor wat ons Belydenisskrifte in hierdie verband sê. 
a. Nederlandse Geloofsbelydenis (NGB).

Art. 24: Ons glo dat hierdie waaragtige geloof in die mens gewerk deur die gehoor van die Woord van God en die werking van die H. Gees, hom w'ederbaar en tot 'n nuwe mens maak, hom 'n nuwe lewe laat lei en hom vrymaak van die slawerny van die sonde...

b. Heidelbergse Kategismus (HK).

1. Vraag 8: Ja (mens heeltemal onbekwaam tot enige goed...) tensy ons deur die Gees van God wedergebore word.

2. Vraag 54: Dat die Seun van God ... vir Hom 'n gemeente... deur sy Gees en Woord... vergader, beskerm en onderhou;...

c. Dordtse Leerreëls (DLR).

1. Hoofstuk I.3: Om dan mense tot die geloof te bring, stuur God... verkondigers van hierdie blye boodskap... Deur hulle diens word mense geroep tot bekering en die geloof in Christus...

2. I.7: Om hulle (uitverkorenes) deur Hom (Middelaar) salig te maak, het $\mathrm{Hy}$ (God) ook besluit om hulle aan Hom te gee en kragdadig tot sy gemeenskap deur sy Woord en Gees te roep en te trek.

3. III en IV.3: ... alle mense... kan en wil ook nie tot God terugkeer nie... sonder die genade van die H. Gees wat die wedergeboorte skenk.

4. III en IV.6: Wat dus die lig van die natuur of ook die Wet nie kan doen nie, dit doen God deur die krag van die $\mathrm{H}$. Gees en deur die Woord of die bediening van die versoening.

5. III en IV.8: Maar almal wat deur die Evangelie geroep word, word in alle erns geroep. Want God gee ons... in sy Woord te kenne wat Hom welgevallig is...

6. III en IV.9: ... ander neem dit wel aan, maar nie in die binneste van hulle harte nie, sodat hulle na 'n kortstondige vreugde van die tydelike geloof weer terugval.

7. IIl en IV.Il: Verder, wanneer God ... die ware bekering in hulle werk, dan laat $\mathrm{Hy}$ an hulle nie alleen uiterlik die Evangelie verkondig nie en verlig Hy nie alleen hulle verstand kragtiglik deur die H. Gees nie...; maar Hy dring ook in tot in die binneste dele van die mens met die kragtige werking van dieselfde Gees wat die wedergeboorte skenk; $\mathrm{Hy}$ open die hart wat gesluit is...

8. III en IV.12: Dit is die wedergeboorte, vernuwing, nuwe skepping... wat God sonder ons in ons werk. En dit word in ons nie teweeggebring deur middel van die uiterlike prediking alleen... Maar dit is 'n geheel bowenatuurlike, baie kragtige en tegelyk baie soete, wonderbare, verborge en onuitspreeklike werking wat... in sy krag nie minder of geringer is as die skepping of opwekking van die dode nie; sodat hulle almal in wie se harte God op hierdie wonderbaarlike 
wyse werk, sekerlik, onfeilbaar en kragdadiglik wedergebore word en daadwerklik glo.

9. III en IV.16: Maar... die sonde... het die natuur van die mens nie weggeneem nie, maar bederwe en geestelik gedood. Daarom werk hierdie Goddelike genade van die wedergeboorte in die mense nie of hulle stokke en blokke is nie...

10. III en IV.17: ... Net so sluit ook die voormelde bowenatuurlike werking van God, waardeur Hy ons wederbaar, volstrek nie uit en dit stoot volstrek nie omver die gebruik van die Evangelie wat die wyse God as 'n saad van die wedergeboorte en 'n spys van die siel verordineer het nie... Want deur middel van die vermaninge word die genade meegedeel.

1i. V.1: Diegene wat God na sy voorneme roep tot die gemeenskap van Sy Seun, ... en deur die H. Gees wederbaar,...

12. V.7: Want, ten eerste, bewaar $\mathrm{Hy}$ nog in hulle by so 'n val sy onverderflike saad waaruit hulle wedergebore is, sodat dit nie vergaan of weggewerp word nie. Ten tweede, vernuwe $\mathrm{Hy}$ hulle sekerlik en kragtiglik deur sy Woord en Gees tot bekering...

13. V.14: Soos dit God behaag het om hierdie Goddelike genadewerk deur middel van die Evangelie-verkondiging in ons te begin, so bewaar, agtervolg en volbring $\mathrm{Hy}$ dit ook deur die anhoor, die lees en die oordenking daarvan,...

14. V. Dwal. 8: Want hulle loën deur hierdie leer (nl. mens kan wedergeboorte verloor, opnuut en baie maal wedergebore word) die onverderflikheid van die saad van God waardeur ons wedergebore word. Teen die getuienis van die apostel Petrus: Julle wat wedergehore is nie uit verganklike saad nie, maar uit onverganklike (1 Petr. 1 : 23).

III. Oordele oor die betekenis van die uitsprake van die Drie Formuliere.

a. Polman. $\left.{ }^{3}\right)$ Dit lyk asof daar 'n prinsipiële verskil tussen die DLR. en die NGB. is, maar dit is nie so nie. Dan sou daar 'n innerlike teenstrydigheid by Calvyn wees, omclat albei uit hom put. Wel is dit waar dat Calvyn aan die woord wedergeboorte nie altyd presies dieselfde inhoud gee nie. Soms is dit die nuwe lewe, bewus deur die geloof gelewe, wat uitkom in die droefheid oor die sonde en lus en liefde na die Wet van God in alle goeie werke; soms is dit die eerste vernuwende daad van die $H$. Gees, waardeur die verduisterde verstand verlig en die harde sondaar tot dic aanneem van die Evangelie verteder word. Die NGB. sluit by die eerste en die DLR. by die tweede aan.

b. A. Kuyper. $\left.{ }^{4}\right)$ Die Skrif en Belydenisskrifte wys op 'n geheimsinnige agtergrond, 'n wonderbare werking van God (vgl. DLR. III en IV. 12). Word die werdergeboorte egter gesien as die ganse bewuste genadewerk tot by die dood, dan is dit soos die NGB. art. 24 dit stel.

c. C. Vonk.5) Die beperking van die begrip wedergeboorte tot die aanvang van die geestelike lewe kom nie in die Drie Formuliere voor nie _.. soos by Calvyn is daarmee die ganse vernuwing verstaan. By vermelding van onmiddellike wedergeboorte is dit in die DLR. om teenoor dis Remonstrante die tussenkoms van die 
menslike wil uit te skakel, hoewel die Woord as middel behoue bly. Ook word wedergeboorte en bekering as geheel behandel (DLR. III en IV. 10-12). Hy maak ook melding van disputasies en uitsprake op die Dordtse Sinode, ${ }^{6}$ ) bv. van Engelse teoloë: „Hieruit (nl. Jes. 59 : 21) blyk dat die Woord en die Gees ongeskeie uit die belofte Gods in die diens van die Woord saamgevoeg word; daarom word die dienaars van die $\mathrm{N}$. Testament genoem dienaars van die Gees, die lewendmakende Gees (2 Kor. $3: 6$ ) en nie van die letter wat doodmak nie."

\section{Skrifgegewens.}

Die woord wedergeboorte kom as sodanig nie veel in die Skrif voor nie (Matth. $19: 28$; Titus $3: 5$; 1 Petrus $1: 3,23$ ). Oor die saak self word tog ook gehandel (Joh. 3; 1 Joh. 3 : 9; 2 Kor. $5: 17$; Efas. 2 : 10; Hebr. 6 : 6, en ook in Ps. 51 : 12; Eseg. $11: 19 ; 36: 26$ ev.). Dit is dus noodsaaklik dat ons die betekenis van hierdie tekse probeer bepaal, maar ons beperk ons hoofsaaklik by wat Petrus hieroor sê.

a. 1 Petrus 1 : 3. "...God ... ons die wedergeboorte geskenk het tot 'n lewende hoop deur die opstanding van Jesus Christus uit die dode,..." In die grondtaal is dit wederbaar (ww.) en die tydsvorm (part. aor.) dui aan: dit het reeds gebeur, was 'n historiesc feit wat gegeld het vir Petrus en die lesers. God is hierin die werkende, en enige gedagte van menslike medewerking of voorafgaande werking is uitgesluit. Die uitdrukking sê dat die nuwe of verwekte lewe tevore nie só bestaan het nie dog dood was, maar dat God se herskeppende almag dit tot aansyn en nuwe lewe gebring het. Duidelik word verder die verband aangelê met die opstanding van Christus - en ons dink aan die gebeure in Petrus se eie lewe, met die omwenteling van die vertwyfeling en verslaenheid tot heerlike troos en vastigheid. Daarom sê Greydanus:7) „Maar de opstanding als zoodanig, als het opkomen van onzen Heiland uit den dood in het leven, is toch metterdaad en voor alle geloovigen het begin en beginsel van hun nieuwe leven en hopen". b. 1 Petrus $1: 23$. "... want julle is wedergebore nie uit verganklike saad nie, maar uit onverganklike, deur die lewende Woord van God wat tot in ewigheid bly." Dieselfde werkwoord (as $1: 3$ ) word gebruik, maar die tydsvorm (part. perf.) spreek van blywende resultate van die afgelope handeling. Dit gee die grond aan waarom Gods kinders kan liefhê (vs. 22). Die aanduiding van hoe die wedergeboorte plaasvind, is vir ons van groot belang.

Die verganklike sien op tydelike, aardse, natuurlike dinge (vgl. vs. 18 - silwer en goud) en die onverganklike op die ewige, geestelike, wat van God kom (vgl. vs. 4 - erfenis in hemel). Die woord spora (saad) kom in die N.T. net hier voor, en kan aandui die saaiery of dit wat gesaai word - hier waarskynlik die laaste (vgl. Greydanus ${ }^{8}$ ). Dan staan daar uit die saad ( $e k$, wat oorsprong of grond aandui) en deur die woord (dia met genitief, wat die middel aandui). In 1 Kor. $3: 6$ ev. onderskei Paulus tussen plant en natmaak, en ons kan feitlik net so 'n parallel hier sien tussen planting en ontkieming wat albei met die 
aanvang van lewe te doen het. In die lig van vs. 3 kan ons sê dat die wedergeboorte uit God is wat die middel van die woord daarvoor gebruik.

Wat word verder met woord (logos) hier bedoel? Dit word omskryf as lewend en blywend (vgl. in vs. 24.v. die kontras met tydelikheid, verganklikheid). Met lewend word aangedui: dit hét en wérk lewe; en blywend sê: dit vergaan nie. Hierby merk Greydanus ${ }^{8}$ ) op: „En omdat dit Woord zoo machtig en heerlijk en Goddelijk is, daarom is ook zijn werk en uitwerking zoo wonderbaar". Ook moet daarop gelet word dat Petrus hierna sê dat dit woord (rêma) is wat aan hulle verkondig is (vs. 25) - letterlik ,,ver-evangelie", en dit wys heen na die daadwerklike verkondiging aan die gemeente.

c. Jakobus $1: 18$. „Volgens sy wil het $\mathrm{Hy}$ ons voortgebring deur die woord van die waarheid...". Tereg wys vs. 17 daarop dat alle goeie gawes van die ewige God kom. Dan word die wonderlike gawe van God beskryf, naamlik dat $\mathrm{Hy}$ ons voortgebring het. Hierdie woord is al gebruik (vs. 15 - sonde bring dood voort), nou van God se werk en gewoonlik word dit van 'n vrou gebruik, as aanduiding van die volledige-ter-wêreld-bring. Dus by hierdie werk van God het ons met 'n deurlopende proses te doen wat gewis sy einde sal bereik. En die ware woord is die middel waardeur God wederbaar en dit wys heen na die prediking van die Evangelie.

Hierby moet ons ag gee op aanmerkings van Grosheide: ${ }^{9}$ )

1. Jakobus sê nie dat die wedergeboorte deur die Evangelie geskied nie, want die Griekse woord (apokuein) wys dat hierdie daad tot die einde toe met sy resultaat geneem moet word en die ons dui op volwasse Christene wat die versoeking moet deurstaan. God laat uitgegroeide Christene ontstaan deur die prediking.

2. Oor die wedergeboorte deur die Woord - dogmaties verstaan - word hier niks gesê nie, want dit gaan oor die Christen-word in die algemeen, oor hoe God ons tot bewuste Christene gemaak het.

d. Jakobus $1: 21$. „... en ontvang met sagmoedigheid die ingeplante woord, wat in staat is on julle siele te red". Dis nie ingebore nie maar word ingeplant, en dit word één, groei saam, nadat die woord (van God - vs. 18) ontvang is. In vs. 18 is gesê dat hulle ter wêreld gebring is (wys op herskepping) deur die woord, en dit moet aanvaar word (dechomai), meer saamgroei en so die slegte verdring - die reaksie op God se aksie.

V. Nadere bepaling van die begrip "Woord".

Dit is vir ons onderwerp nodig dat ons duidelikheid het oor wat presies onder Woord verstaan word. Reeds by die begripsbepaling is aangedui dat daar onderskeie betekenisse is, en terwyl skrywers in hul interpretasie verskil, moet ons hieroor ons nader besin.

a. Dr. A. Kuyper. Hy sê dat ons in 1 Petrus $1: 23$ nie in die eerste plek aan die H. Skrif moet dink nie, maar dat die siel hom moet ophef tot die ,naar 
Gods raad, met ondoorgrondelijke wijsheid uitgaande, eeuwige en alnogende kracht des Heeren, waardoor $\mathrm{Hij}$ schept en herschept, doodt en leven $\mathrm{I}$ maakt, in stand houdt en verderft".10) Elders betoog hy dat in hierdie verse nie alie Bybel bedoel word nie, want

(i) die Bybel bly nie in ewigheid nee en sal nie gere.1 word uit die wêreldhrand niell);

(ii) die Skrif en prediking is verganklik 12);

(iii) daar is sprake van lewende (dsoontos) Woord en as die Bybel bedoel was sou dit gewees het waaragtige Woord.13)

Die lewende Woord van God in I Petrus is die bevel van God, Sy ordinansie oor sy uitverkore kind waardeur $\mathrm{Hy}$ gelas dat die saad sal gaan werk en opskiet - nes in Matth. $4: 4$ die woord ook die ordinansie van God is (vgl. Deut. $8: 3$, 18) en dit het nie met die Bybel te doen nie. 14) Ons het hier met die Skenpingswoord te doen,12) maar die Woord van God het nie net by die skepping gekom nie, ${ }^{10}$ ) dog bly voortdurend en daardeur bestaan die wêreld, 11 ) en Petrus spreek hier dus van die goddelik herskeppende krag, wat deur die Woord tot stand kom.15) Alles is uit (ek) die Vader en deur (dia) die Seun; die Vader handhaaf die syn, maar die voortdurende insyn van die Logos bepaal die hoe van die wêreld.11) In die ewige Woord is tog die volheid van die gedagtes van God en alle dinge is deur die Woord geskep (en in elke ding is 'n gedagte van God uitgedruk). Terwyl dic wedergeboorte herskepping is, sluit dit aan by dic geboorte en daarom is by die herstel ook die samewerking van die drie Goddelike Persone -. dis uit die Vader, deur die Woord en kragtens die H. Gees. 15)

Tog is daar vanselfsprekend verband tussen die ewige Woord en die Skrif. Kuyper sê dat in 1 Petrus 1 : 25 onderskei word tussen die Skrif en die prediking van die Skrif aan die een kant en die lewende Woord van God (waarvan die H. Skrif die uitdrukking is) an die ander kant. In Petrus se tyd was die Evangelie nog nie in geskrewe vorm nie, en wat dus die geloof wek of wederbaar, is lewend en blywend en is dus die Woord van almagtige genade wat dit soms tot ons kennis bring. Maar die H. Skrif kan nooit los van die lewende God gedink word nie, omdat God verkies het om deur die Skrif te spreek en die II. Gees pas dit in elke hart toe - daarom is die Skrif nooit los van die H. Gees nie en Hy lê getuienis van Sy eie werk in die siel af.10) Dit is dus die herskippende spreke van hierdie "lewende Woord" wat die gelowiges ook in die afgeleide woord van die openbaring beluister het, en dis die stem van God wat die Evangelie tot Fvangelie maak.15)

Kuyper haal met instemming aan die uiteensetting van die „grootste gereformecrde teolong" (Voetius?) oor die goddelike gedaglegang in die werk van die wedergeboorte wat hy in die volgende stadia probeer weergee het - om ons voorstelling tegemoet te $\mathrm{kom}-16$ ):

(i) God dink in sy gedagtes die nuwe mens;

(ii) God wysig in sy goddelike denke die nuwe mens volgens die karakter van 'n bepaalde persoon en skep dus ons nuwe mens;

(iii) die kiem wat dit in hom vervat, dra Cod in die sentrum van ons wese in;

(iv) in die sentrum van ons wese bring die Here die vereniging lot stand tussen hierdic kiemende lewe en ons ek;

(v) God onderhou in die lewenskiem, en laat op sy tyd daaruit werk, die vormende krag waardeur ons ek as 'n nuwe mens openbaar word.

Sy eie beskouing gee hy soos volg weer: „Met de wedergeboorte worlt ons alzoo ingeplant de levenskiem van een nieuwe mensch, die even zeker in die kiem reeds geheel inzit, en even gewisselijk uit die levenskiem voortkomt, als het graan inzit en opwast uit het koren".16)

Hierdie beskouing bots glad nie met die Skrif of Formulierc nie, want ook 
hulle wys steeds op 'n geheimsinnige agtergrond, op 'n wonderbare werking van (God wat agter dit alles skuil.16) God lê dus die saad van die wedergeboorte in ons direk deur die werking van die Woord as skeppende krag (vgl. 13)). Die inwendige roeping van die mens geskied deur die $\mathrm{H}$. Gees, maar daaragter lê nog die horend maak van die oor - opdat die inwendige roeping verneem kan word en dit is heeltemal nie aan die prediking van die Woord gebonde nie en kan dus daaraan voorafgaan.17) Ilierdie laste is die eerste stadium van die wedergeboorte (God werk alleen, en ons word werkloos gevind en gelaat) en God werk dit sonder middel. Dan volg die tweede stadium, $\mathrm{nl}$. as die wedergebore mens tot bekering kom (waarby Cod ons werkloos vind maar werkend maak), en hierin werk God deur 'n middel, te wete die prediking van die Woord.17)

b. Dr. H. Bavinck. Hy sê dat Petrus die wedergeboorte toeskryf aan God en Sy barmhartigheid (1 Petrus 1 : 3 ), en dit kom tot stand deur middel van die lewende en blywende woord van God, ,hetwelk identisch is met het woord des Evangelies, dat onder zijn lezers verkondigd was, vs. 23,25 ". Die wedergeboorte staan verder in nouste verband met die opstanding van Christus. By 1 Petrus $1: 23$ is dit moeilik on te beslis of die lewende woord van God identies met of onderskeie van die onverganklike saad is, maar die verband laat dink dat dit identies is (vgl. verswyging van saad in $24 \mathrm{v}$. en die teenstelling van gras en woord) - dit wat só kragtig in die lewe hom openbaar moet uit iets lewends voortgekom het en dis die onverganklike saad van die woord van God. Die wedergeboorte is aan God te danke, wat dit deur die opstanding van Christus tot stand bring en deur middel van die lewende Woord dit doen, en daarom is dit wedergeboorte-tot-lewende hoop. ${ }^{18)}$ Elders ${ }^{19}$ ) sê hy dat dit nie reg is om sonder meer te sê dat die wedergeboorte geskied deur die woord van God, d.i. Sy krag nie. Wel het die uitdrukking woord Gods hierdie betekenis in die Skrif, maar Petrus dink tog klaarblyklik ann die woord van die Here soos dit verkondig is. Die woord Gods waardeur die wedergeboorle geskied is nie identies met die Gods woord in die algemeen nie (bv. in skepping en voorsienigheid) maar in die herskepping (d.i. die woord wat Hy in Christus en deur die Gees in die harte spreek).

c. Vonk. Hy sê ons moet duidelik begryp dat dar één Gees is wat roep deur één middel, die goddelike Woord, en hy wat dus aun Gods Woord ongehoorsaam is, weerstaan daarmee die H. Gees.20) Die H. Gees wederbaar of vernuut ons deur die Woord, nl. die Evangelie angaande die Here Jesus Christus.21) As die Dordtse Leerreëls praat van onmiddellike wedergeboorte dan is dit om die Remonstrantse dwaling van die tussenkoms van 'n menslike wil uit te skakel, maar die Woord bly as middel behoue. Verder is dit nie genoeg dat die Woord tot die mens kom en dan moet hy self verder besluit nie (Remonstrante), want die H. Gees dra die Woord in die hart om daar volkome heerskappy te voer - oor daardie hart heeltemal en tot in sy diepste kern. Ons moet ook onthou dat die Woord selfs by die goddelose admissie verkry, dog nie inmissie nie.22)

d. Procksch en Kittel.23) By die profete in die O.T. is die Woord van die Here lewenskrag en met sy verdwyning hou die genade op,24) en by Jes. 40 is die Woord erken as hemelse krag wat skeppend op die aarde werk en sy werk verrig. ${ }^{25}$ ) In Handelinge en by Paulus is die woord gelyk aan boodskap van Christus, bv. in 1 Tim. 1 : 15 word as inhoud van die logos aangegee dat Jesus Christus na die wêreld gekom het om sondaars te red. En al ontbreek nadere bepaling by 1 Petrus I : 23 moet dit só verstaan word: aan die begin van die Christen-wees, daar waar die wederbaring geskied, staan 'n „lewende en blywende woord van God" - maar hierdie woord is volgens vs. 25 niks anders nie as: die woord wat aan julle verkondig is. Eweso is in Jak. $1: 21$ die ingeplante woord die boodskap wat die siele red, en wat in die verkondiging ingeplant is (vgl. vs. 18 - voortgebring deur die woord van waarheid).26) 
Die uiteensetling vervoly dan verder. Wanneer woord identies is met die boodskap van Christus, die Evangelie, dan kan uitsprake oor die Evangelie na goeddunke op die Woord oorgedra word. So is woord 'n boodskap wat 'n werklikheil (aleitheia) uitdruk - . en onthou moet word dat die gewigtigste eienskap van dabar in die 0.T. en sy vertalings in die N.T. (logos en rêma) is dat dit waarheid is. God spreek en die mense bedien dit net - dis nie „an sich” werksaam nie, maar dit werk omdat dit die van God gespreekte en gehandelde Woord is. Daarom werk dit genade, redding, lewe (en verwys nie net daarna nie) omdat dit genade, redding en lewe is - vgl. Jak $1: 21.27$ )

Verder word gesê dat die verhouding van die mense tot die "Woord" in elke opsig ooreenstem met die dialektiek wat die hele N.T. deurtrek, nl. van gryp en gegryp-word. By die begin is die passiewe, soos blyk uit die geboorte in 1 Petrus 1 : 23 en Jak. 1 : 18 (met beklemtoning van $S y$ wil) - die primêre werking deur God gaan vooraf (vgl. 1 Thess. 1 : 6; Hand. 15: 7; Kol. 4: 3; 2 Thess. $3: 1$ ). Maar die Woord moet ook aangeneem word (Hand. $13: 46$ ), in die geloof - want eers deur die .,pisteuein” kom die ,akouein” tot sy doel (Hand. 4: 4; 15 : 7). Daar is egter geen teenstelling tussen hierdie twee lyne nie (vgl. 1 Thess. 2 : 13; Ffes. 1 : 13; Hand. 13 : 48). Die aanneem en glo van die Woord is dan ook eers werklikheil daar war dit gedoen word, anders baat dit nie (Jak. 1 : 21v.; 1 Petrus $2: 8 ; 3: 1$; veral Hebr. $4: 2$ ). By alles bly logos steeds legein - gespreekte woord in sy konkreetheid - en daarom moet die woord steeds verder gespreek word. Alle Christlike teologie en bespieëling, asook alle onderwrsing, vind sy norm of sekerheid in die getrouheirl van die weergawe en deurgawe van die volstrekte geskielenis, die Woord deur God daargestel en in die geskiedenis gespreek (Luk. $1: 1-4$; vgl. Tit. 1 : 9).28)

VI. Besinning oor die wedergeboorte.

Dit is noodsaaklik dat ons ook besin oor wat wedergeboorte is - of wat gereken word dat dit is -- sodat daarna die verband tussen Woord en wedergeboorte bepaal kan word. Ons moet let daarop, soos Bavinck opgemerk het,29) dat die Dogmatiek 'n enger betekenis aan die begrip wedergeboorte gee as die $\mathrm{H}$. Skrif. maar die Dogmatiek probeer hom besin oor die gedagtes wat geopenbaar is. Dit is juis die taak waarmee ons besig is, en ons gee nou eers ten beste die heskouings van verskillende teoloë hieroor.

a. A. Kuyper. Die wondere werking van Gods genade verloop soos volg:30)

(i) wedergeboorte in sy eerste stadium, as die Here die lewe inplant in die hart wat dood was;

(ii) tweede stadium, as die wedergeborene tol bekering kom, en God gebruik die prediking hier as middel;

(iii) derde stadium, as die bekering groei in heiligmaking, en God 'n middel by ons, onsself, gebruik.

Elders 31 ) beskryf hy die wedergeboorte as die inbring van lewe, besnydenis van die hart, omsit van klip-hart, en dis 'n onmiddellike werking wat deur niks voorberei word nie. Verder ook dat die vermoë om te glo deur die wedergeboorte ingelê word (soos 'n baba die vermoë het om te praat en dit nog nie doen nie), maar die gebruik en aanwending van die vermoë (werklik te glo) werk God alleen deur die Woord, onder leiding van die Gees. ${ }^{32}$ ) Nie die wese van die mens is deur die sonde verniel nie mar wel sy natuur. en in die wedergeboorte word nou hierdie natuur herbore _. soos 'n goeie loot wat op 'n wilde stam geënt word. Maar hierdie saad van die wedergeboorte is iets geesteliks en nie waarneembaar nie. ${ }^{33}$ ) God alleen dring in die kern van die mens se wese in, on die steurnis van die natuur te verwyder - dis 'n bonatuurlike daad waarby die mens geensins meewerk nie, en die aksie vloei eers daaruit as God lewendig 
genlak het. 34) Daarom moet in I Petrus $1: 23$ die dia kousaal gelees word (naus el), en tlie ,causa unde" is God.35)

bit blyk nou dal Kuyper se standpunt is dat die wedergeboorte, as daad van God alleen, in die mens gewerk word sonder die verkondiging van die Woor( ${ }^{36}$ ) (hoewel nir buite die Logos as ewige krag nie) in die prediking en dat die verkondiging ecrs te pas kom loy die bewuswording of -making van die wedergeboorte in die gcloof. Dus is die wedergeboorte die saal waaruit die ander stardia groej. Tor ste hy ook dal as die eerste daar is, moet die ander volg en so kan die hele genadewerk beskryf word as 'n gebore word vir die hemel.37)

Maar hoe en wat werk die wedergeboorte in die mens? Hieroor sê hy dat enige moontlike serlelike werking deur die mens uilgesluit is, en so word ons oortuig dal lit in fisieke dat is - net soos die inskep van die siel deur God in die ongebore kind. Buite die voorwete van daardie persoon gaan God die Here in hom in en doen iels aan hom en daardie iets alleen wederbaar. ${ }^{38)}$ Dis onmiddellik, leur nik; voorberei nic en dieselffe by die grootste misdadiger as by die onskuldigste kind 31 ) (Oll met Christus verenig te word, is geen voorafgaande reiniging nodig nie, maar wel die aanlê van in band aan Hom maar daar is geen mistieke band met die Immanuel behalwe in die wedergeboorte nie.39)

On Kuyper se gedagtes saam te val: Die wedergeboorte is 'n daad van God, deur die Logos, kragtens die 11. Gees, wat die band met die Imnanuel aanlê en die legin van alle verdere genalewerk (deur God en van die mens) is en dit fundeer ons band mel Christus in die genadeverbond

b. Vonk. Die gelykenis van die suad op die akker wil nie sê dal mense gevoelloos

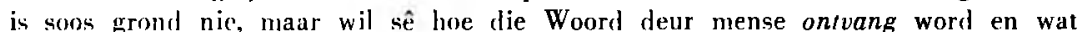
hulle daarmee doen. Volgens die DLR. begin God sy werk van genade in ons fleur dic prediking van die Evangelie (V.14) - die H. Gees gebruik die Evangelie en verordineer dit tol die saat van die wedergeboorte en spyse van die siel. Dis egler nie in in fatalisliese gees nic, want dan kon die prediking swyg. Jesus tog vermain herhaaldelik om le hoor. En waar ons opgewek word, mag ons nie gaan spreck oor wat (rod moet doen nie, omdat dit die aandag aflei van die bevel tot geloof en bekering. 40 )

c. Bavinck. Ity poneer dal by die begin van die Christelike kerk en by elke nuwe religicuse beweging (bv. Hervorming, Metodisme) aangevang word met die mitnodiging (in (n deur die Woord), en dil bly op die voorgrond solank die Evangelie met volwassenes te doen hel. Die situasie verander egter sodra die kerk te doen kry mel die kinders van die gelowiges of by verdieping van die besinning, want dan word besef dat daar nie by die mens en sy wil vasgesteek kan word nie maar moet daar gelet worl op God se werk wat daaragter lê.41) So noem hy dit dat taar by die Cereformeerdes ooreenstemming was dat die beginsel en aanvang van die nuwe lewe in die mens net te danke was an die inwendige, regslreekse, kragrladige en onverwintare werking van die H. Gees. ${ }^{42}$ )

Hy coon verder aan dat die gedagte van die wedergeboorte in die O.T. wortcl - eers van die volk as geheel en met die toename van sonde, van die lode van die volk. Hierdie inwendige verandering word deur Johannes die Doper geëis - vir goeje vrugte moet dic hoom eers goed genaak word. Die JohannesEvangelie hots nie met die ander Evangelies nie, dog bied net sistematisering. By Panlus is dic saak opgesluit in die kragdadige roeping. Die O. en N.T. stem ooreen dat dit allyd in volstrekte sin die werk van God is waardeur die mens innerlik verander en vernuul word. Die diepsı oorsaak daarvan lê in Gods barmharligheid. dis gegrond in die opstanding van Christus, kom tot stand in gemeenskap met $110 \mathrm{~m}$, van Wie die Woord getuienis gee en dit openbaar hom in 'n heilige lewe. Soms (Johannes) val die klen meer op die beginsel van die nuwe lewe, mel gelowige hoor en anneem van die woord wat volg; soms is die ander sy 
voorop, nl. ontplooiing en ontwikkeling van die nuwe lewe - maar ,beide zijn loch ten innigste verbonden, en hooren in het ééne begrip der wedergeboorte onaf-cheidelijk bijeen".44)

Die wedergeboorte gaan steeds vooraf aan die salutariter audire van die woord, maar nie noodwendig aan die uitwendige hoor of sedelike werking wat van die woord op hart en gemoed uitgaan nie (vgl. Hand. 16: 14; Eseg. 37 : 14v; Joh. 11 : 43v.; Rom. 4 : 17).45) Dit gaan ook logies vooraf aan geloof en bekering. Daarom het die Gereformeerdes gestel ,dat de uitwendige roeping en zedelijke aanraking door het woord onvoldoende was tot zaligheid, maar door eene gansch bijzondere werking des $H$. Geestes in het hart des menschen gevolgd moest worden".46) Daarom het hulle gesê hierdie werking is onmiddellik, verder onweerstandelik en dis omskryf as 'n operatio physica (vgl. DLR.).47)

Maar wat is die wedergeboorte nou in die mens self? Bavinck sê die H. Skrif gebruik verskeie terme wat hier 'n aanduiding gee, $n$ l. besnede hart, vaste gees, nuwe skepsel, Gods maksel, en veral ook dat hy 'n geestelike mens word en dit kom daarvan dat die Gees van God ontvang is waardeur Christus in daardie mens is. Omdat die sonde die mens heeltemal bederf het, sê die Skrif duidelik dat die wedergeboorte ' $n$ algehele vernuwing en herskepping van die mens is. Dis egter geen nuwe of tweede skepping, waardeur nuwe substansie in die skepping gebring word nie, maar dit gee terug wat ons wesenlik moes hê en deur die sonde verloor het. sodat ons in beginsel na die beeld en gelykenis van God herskep word. Dis moeiliker om positief te sê wat wedergeboorte is, want dis 'n groot misterie oin te omskryf hier waar die ewige die tydelike, die Skepper die skepsel, raak. Tog kan gesê word dat die ganse mens subjek van die wedergeboorte is - die mens self word omgesit en vernuut in die kern van sy wese, die hart. Dis 'n geestelike vernuwing van die innerlike gesindhede van die mens, 'n nuwe habitus. Wel is daar nuwe hoedanighede, maar dit was oorspronklik by die mens (DLR. III en IV.12). Van dwang is daar geen sprake nie, eerder is daar bevryding van die dwang van sonde. En die H. Gees verleen ook aan die ingestorte kwaliteite 'n duursame karakter, want vastigheid word ontleen aan die blywende gemeenskap van die $H$. Gees. ${ }^{48}$ )

VII. Wedergeboorte en vroeg-sterwende kinders.

Die DLR. sê in I.17: „Aangesien ons oor die wil van God moet oordeel uit sy Woord wat getuig dat die kinders van die gelowiges heilig is,... kragtens die genadeverbond... daarom moet Godsalige ouers nie twyfel aan die uitverkiesing en saligheid van hulle kinders wat God in hul jeug uit hierdie lewe wegneem nie..." Hoewel hierdie saak nie direk met ons onderwerp te doen het nie, moet ons dit $\log$ onder oë sien, juis ook omdat daar verskil van opinie is.

a. A. Kuyper. By die wedergeboorte is enige moontlikheid van sedelike werking deur die mens - of medewerking - uitgesluit, want dis 'n fisieke daad van God. Die Skrif sê selfs rlat dit in die moederskoot kan plasvind waar beslis geen medewerking kan wees nie. God tog wederbaar uit die dood tot die lewe deur die H. Gees regstreeks en onmiddellik, en dis dieselfde of die mens groot of klein (i.c. vroegsterwende $k$ ind) is. Dis tog die inplanting van die geloofsvermoë. Daarom kan alleen mar gesê word dat die wederbarende werking van die H. Gees voor, met of $n a$ die gehoor kom.49) Oor die tyd van die vereniging met Christus sê hy dat dit in stadia verloop, nl. (i) in die besluit van God, (ii) in die vleeswording, as dit uit die besluit in die werklikheid tree, (iii) in die wedergeboorte, as God sy hand aan ons lê, dan is die band gelê, (iv) in die bewuste geloofsuiting (daarmee subjektiewe vereniging), ( $v$ ) in ons dood. Hierdic vereniging vorm die grondslag van die verbondsbetrekking met Christus.50) 
b. Vonk. In Joh. 3 word tot 'n volwassene gespreek en aan hom gesê dat hy vernuut moet word om in die koninkryk van God te kom. Dieselfde staan in Eseg. $18: 31$; 1 Kron. $6: 10$; Openb. $21: 27,22: 14$. Daarom mag ons nie uit Mark. 16 : 16 só redeneer dat kin'ers nie kan glo nie en op grond daarvan die teorie opstel dat geloof, bekering : . s.ergeboorte deur die Gees sonder die Woord gewerk word nie. Dan kwoteer hy uit die besprekings op die Dordtse Sinode, waar o.a. Gen. $17: 7$; Matth. $19: 14$ en Hand. 2:39 angehaal is en gekonkludeer is: "Uit hierdie plekke word vasgestel dat die kinders van die gelowiges wat in hul kindsheid sterwe onder die uitverkorenes gereken moet word, terwyl hulle genadiglik deur God uit hierdie lewe verlos is voordat hulle die voorwardes van die verbond verbreek het. Maar in vesband met die kinders van die ongelowiges, wat buite die gemeente van God is, reken hulle dat dié kinders aan Gods oordeel oorgelaat moet word. Want diegene wat buite is, sal God oordeel, I Kor. 5 : 13." Verder sê Vonk dat ons die kinders wat God nié vroeg van ons wegnecm nie, so vroeg moontlik onder die beademing van Gods Woord moet bring, sodat die $\mathrm{H}$. Gees hulle en ons harte gestadig neig tot die vrese van God.51)

c. Bavinck. In die tyd van die Reformasie was die Gereformeerdes eenstemmig oor die volgende punte:

(i) die weldade van die genadeverbond is in die reêl deur God i.v.m. die genade-middele uitgedeel, dus wedergeboorte ook i.v.m. die woord;

(ii) maar God is nie aan die middele gebonde nie en kan die ongewone weg volg, bv. vroegsterwende kinders sonder woord wederbaar;

(iii) in die reêl is dit so met vroegsterwende kinders van gelowiges;

(iv) gedoopte kinders moet vir uitverkore en wedergebore gehou word, totdat die teendeel uit belydenis en wandel blyk;

(v) dis egter oordeel van die liefde wat nie onfeilbaar is nie.52)

Verder is dit so dat die H. Gees die wedergeboorte aan volwassenes en kinders kan skenk, want ly beide geskied dit sonder hulle wil en voor die geloof. Die roeping is deels uitwendig en deels inwendig, en so sluit die daad van God in die wedergeboorte 'n sedelike en 'n "hiperfisiese" werking in - e.g. deur die woord, gerig op die bewussyn en daardeur heen op die wil. Verder sê Bavinck dat die Christelike kerk, op grondslag van die trinitariese dogma, eenparig 'n gratia infusa bely. Die Roomse en Lutherse bind hierdie instorting van genade (wedergeboorte) by die kinders aan die doop, maar die Gereformeerdes het by Skriflig leer insien „dat de kinderen der gelonvigen niet door maar reeds vóór den doop, niet om hunne ouders en krachtens hunne natuurlijke geboorte, maar met hunne ouders krachtens Gods ontferming in het verbond der genade begrepen waren. Bij hen kon de wedergeboorte dus plaats hebben, zonder de uitwendige roeping door het woord. Uitwendige en inwendige roeping, woord en Geest, de moreele en de hyperphysische werkzaamheid Gods in de wedergeboorte gingen dus in de werkelijkheid dikwerf vrij ver uit elkander".53)

Tog moet die verband bewaar bly (teenoor Wederdopers) en daarom is geleer dat die genaleverbond aan die wedergeboorte voorafgaan, dit lêt objektief as 'n genadige ordening van God vir hulle gereed - dit bestaan onafhanklik van hulle in die Evangelie en die sakramente, en hulle word passief daarin opgeneem en nou as lede van daardie verbond gedoop. Die sakrament van die doop sou geen sakrament wees as dit nie as 'n teken en seël aan die woord geheg was nie. Die inwendige roeping, waardeur die kinders wedergebore word, bly dus objektief ten nouste met die woord in verband staan, al is dit dat die kinders self nog nie bewussyn daarvan het nie. As die wedergeboorte objektief van die Woord losgemaak word, sou tog oor die teenwoordigheid en werksaamheid van die Gees nie meer te oordeel wees nie. Dit sou ook dié konklusie kon uitlok dat Christus se 
persoon en werk eintlik nie meer vir die saligheid nodig is nie en dat God die sondaar ewegoed deur die Gees alleen, sonder Christus, kan wederbaar.

VIII. Opmerkings - Opsommend en krities.

Voordat ons by die konklusies kom, wil ons graag 'n paar opmerkings maak, om nie die tetiese gedeelte daardeur te onderbreek nie.

Opvallend is dit dat Kuyper baie duidelik uitspreek dat dic woord wat die wedergeboorte werk, nie die verkondigde Woord is nie. Treffend in hierdie verband is die opmerking dat die dia (in 1 Petrus 1 : 23) kousaal gelees moet word. (VI.a) Dit is egter nie korrekte eksegese nie, aangesien dia met die Genitief nie kousaal gelees kan word nie, maar wel instrumenteel - dit dui die middel aan. Hoewel Kuyper die verband tussen die ewige Woord en die Skrif wil handhaaf, val die klem vir hom beslis op die Woord as spreke of as ewige krag van God, en die hoofsaak by die wedergeboorte is die inplant van die geloofsvermoë, ook omskryf as die saad van die wedergeboorte. Dit is ook te veel gesê as hy beweer (V.a.) dat as Petrus die Skrif bedoel het (in 1 Petrus 1 : 23) daar geskrywe sou staan ,waaragtige” en nie „lewende" Woord nie vgl. Hand. 7 : 38 en Hebr. 4 : 12.

Ons het verneem (V.b) dat Bavinck meen dat, hoewel woord die hetekenis van Gods $\mathrm{krag}$ in skepping en herskepping kan hê, dit veral by 1 Petrus nie só gelees moet word nie - daarmec opponeer hy dus vir Kuyper, al is dit nie by name nie. De Groot ${ }^{54}$ ) wys daarop dat Kuyper wel praat van die kiem (van die nuwe lewe) maar dis niks stofliks nie (vgl. VI.a), en voeg niks vreemds aan die menslike aard toe nie, maar die mens wat dood was, word lewend gemaak. Die bedoeling van hierdie terme, meen De Groot, ${ }^{55}$ ) is om aan te dui dat dit goddelike werk is en van buite af ingedra word, en selfs dic Skrif gebruik soortgelyke beeldspraak (Matth. 15 : 13; 19 : 26; Rom. $5: 5$; l Joh. 3 : 9). De Groot se beskouings stem baie ooreen met die van Kuyper, en hy sê ook dat haie van die kritiek op Kuyper nie geregverdig is nie, omdat hy nooit gestel het dat die kiem 'n selfstandige lewensbeginsel is wat uit eie inherente krag verder ontwikkel nie. ${ }^{56}$ ) Tog moet ons instem met sy opmerkings dat hierdie terme gevaar inhou en ook onvolledig is, aangcsien: (i) naas die lewendmaking deur die H. Gees daar ook doding van die sondige natuur plaasvind, en (ii) dit swyg oor God van Wie alles afhanklik is en bly, en dit ook te kort doen aan die sentrale betekenis van Christus vir die wedergeboorte. ${ }^{57}$ )

Wat Vonk se uitsprake betref, moet aangeteken word dat dit stellig te kras gestel is as hy sê dat die Drie Formuliere nie dic begrip wedergeboorte beperk tot die aanvang van die geestelike lewe nie (III.c). Ons meen dis duidelik dat dit tog ook daarin voorkom (vgl. DLR. III en IV.12) en dat dit beslis ook by Calvyn voorkom, uit wie die Formuliere baie uitsprake geput het. Aandag moet verder gegee word aan Bavinck se opmerking (VI.c) dat wanneer die kerk ontplooi (na 'n 
vernuwing) en daar met kinders van die gelowiges en met diepere besinning te doen gekry word, ook besef word dat die beklemtoning van dic nodiging van die Evangelie nie genoegsaam is nie. Daarom skyn Vonk se allénige beklemtoning van die gehoor-gee aan die Evangelie en die aanduiding dat wedergeboorte nie beperk mag word tot die begin van die vernuwing nie, beslis eensydig te wees.

Dis verder nodig om teenoor mekaar te stel Vonk se uitspraak (V.c) dat die Gees net deur één middel werk en Calvyn se woorde: „Dit is nie versigtig genoeg om aan die Here die vermoë te ontsê dat Hy Hom aan die kinders op een of ander wyse kenbaar sou kan maak nie."58)

Dit moet uit alles duidelik wees dat ons by die wedergeboorte met 'n ingrypende en tegelyk misterieuse werking van God te doen het. Die Skrif stamel self as 't ware daaroor en die besinning sal dus noodwendig nie in alles duidelik kan spreek nie. Wel staan dit vas dat daar aan of in die mens iets verander of herstel word. Nie 'n totaal- of wesenliknuwe mens word geskep nie, maar die oue word herskep, omdat die sonde verwoes en gedood het. Dit geskied deur die Woord van God in een of ander vorm en op een of ander wyse. Mense kan dit nie bewerk nie nog die mens self aan homself of die prediker van die Evangelie deur eie krag. Gods Gees moet ingryp en voordat die mens gelowig hoor, moet die Gees hom horend maak - anders sal alles langs hom verbyvloei. Daarom kan ons verstaan en regverdig dat die Gereformeerde teoloë gespreek het van 'n gratia infusa (vgl. DLR. III en IV.11, 12), van 'n fisiese of hiperfisiese daad. Nooit is of kom die mens egter los van God, van Christus en Sy werk, van die H. Gees en Sy inwerking nie, al span God die mens self ook in.

IX. Konklusies.

Sonder die genadige inwerking van God in die mens kan daar geen wedergeboorte wees nie. $\mathrm{Om}$ te weet wat dit is, moet ons die openbaring van God in die H. Skrif naspeur. Dit moet egter in gedagte gehou word dat ons met werke van God te doen het - die DLR. sê dis 'n wonderhare, verborge en onuitspreeklike werking - en dat dit stellig moeilik is om dit adekwaat te beskryf. Maar besinning oor wat die Skrif hieroor bied, is moontlik en inderdaad ook nodig, sodat steeds die hele Raad van God verkondig kan word (vgl. Hand. 20 : 27). Daarom wil ons poog om enkele hoofsake aan te dui.

a. Die onmisbaarheid van die wedergeboorte.

Ons lees in Joh. 3 dat Jesus aan Nikodemus sê: „Voorwaar, voorwaar Ek sê vir jou, as iemand nie weer gebore word nie, kan hy die koninkryk van God nie sien nie" (vs. 5: koninkryk nie ingaan nie). Die sien of ingaan in die koninkryk verwys duidelik na die verkryging van die ewige lewe. En nou stel Jesus as voorwaarde daartoe die weder-i 
geboorte, d.i. soos die mens van nature en in homself is, kan hy nie die ewige verlossing verkry nie, aangesien daar verandering of vernuwing moet intree, 'n nuwe geboorte.

Die aandag moet daarop gevestig word dat Jesus hier met Nikodemus, 'n volwasse man, spreek. En aan hom sê Hy: iemand moet wedergebore word. Hier word in die Grieks die onpersoonlike voornaamwoord (tis) gebruik. Grosheide ${ }^{59}$ ) sê dat die geval so algemeen moontlik gestel word, dit geld elkeen. Maar dui dit nou elkeen, in die sin van almal, aan of miskien net: elkeen soos Nikodemis, elke volwassene? Indien dit almal voor die voet wil aandui, sou daar dan nie miskien eerder gestaan het: Niemand sal die koninkryk van God sien tensy hy wedergebore is nie (oudeis i.p.v. tis). Ons moet verder daarmee rekening hou dat dit 'n lewende gesprek is wat ook deur die situasie bepaal word. Vergelyk hierby Markus 16 : 16 se eis van geloof en doop vir redding, waarby Gereformeerdes saamstem dat dit tog nie die kinderdoop diskwalifiseer nic, aangesien dit ' $n$ eis is aan volwassenes by wie die Christelike Kerk moes begin het. Miskien kan Jesus se woorde in Joh. 3 ook soortgelyk verstaan word.

Ons noem hierdie moontlikheid omdat dit invloed mag hê op die bepaling van sake vir ons onderwerp, spesiaal met betrekking tot die kinders. Verder moet ons by die wedergeboorte altyd bedug wees vir dié gevaar dat ons 'n lyn wil trek en sê: Tot hier werk God direk en daarna werk die mens ook of God indirek. Dit mag moontlik beter wees om Gods werk en ons werk in sy totaal te sien as twee kante van een saak. Daardeur mag ons miskien ook ontkom aan die dilemma van wedergeboorte in enger (eerste begin) en ruimer sin (hele nuwe lewe).

b. Die wedergeboorte as sodanig.

Indien Joh. 3 'n absolute eis bevat vir elkeen en almal geld, dan moet die oplossing in 'n bepaalde rigting gesoek word. Dan sal dit ook noodsaaklik wees om te kom tot ' $n$ suiwering van begrippe.

Aan die geboorte van ' $n$ mens moet voorafgaan die verwekking in die moederskoot - dáár tog is die eintlike begin van 'n nuwe lewe, met 'n daad wat deur die man verrig word. Nou is dit opmerklik dat in die Grieks 'n bepaalde woord hoofsaaklik gebruik word vir die wedergeboorte waarby die werksaamheid van die man aangedui word.60) Dit mag dan dalk heter wees om vir die aanvang van die nuwe geestelike lewe te gebruik die begrip van weder-verwekking - iets wat ook sal aandui die totale onmag en onbekwaamheid van die mens in hierdie saak. Soos die ontstaan van elke mens 'n wonder van God is, so ook van die nuwe geestelike mens. Die werksaamheid van God is die begin van dic nuwe lyn.

Hierby lees ons dan Jesus se sprake in Joh. 3 oor die werking van die H. Gees by die wedergeboorte. Jesus gebruik die beeld van die wind. Treffend is daarby dat jy nie die wind kan sien of vasgryp nie, en selfs 
gewoon-menslik nie sy oorsprong kan bepaal nie. Jy hoor die wind ook alleen as dit teen of deur iets waai, d.i. sy werkinge of gevolge is bekend en aanwyshaar. Só, sê Jesus, is daar 'n vrymagtige en onnaspeurlike werking van die Gees, maar die gevolge of vrugte kom aan die lig. ${ }^{61}$ ) Dink ook aan die goeie vrugte wat alleen van 'n goeie boom kan kom. In Joh. 3 : 8 sê Jesus: ...So is elkeen wat uit die Gees gebore is" - en die werkwoord is gennan (verwek), en in die perfektum wat aandui dat die gehoure voltooi is maar dat die werking deurgaan. Ons sou hier wil sê: die Cees bly werk! Die nuwe lewe van die mens is nooit iets self. standigs nie, dog bly altyd afhanklik van die werking van Gods Gees wat soos 'n telkens-verfrissende wind die tuin moet deurwaai.

Hierdie werking van die Gees is inderdaad wonderbaar en verborge -. soos wat dit die geval is met die verwekking van 'n kind in die moederskoot. En die Gees werk hierin soos die wind - wonderlik, onuaspeurlik, maar die gevolge daarvan is waarneembaar en bepaalbaar. Die weder-verwekking self is en bly geheimnisvol, juis omdat dit die menslike, skepselmatige is wat deur die almagtige en skeppende God aangeraak en verander word. Dit werk God inderdaad sonder ons in ons -- dus buite ons wil en bewussyn om. Van die wedergeboorte kan ons dan nog met gerustheid spreek as van die begin van die selfstandige en hewuste lewe van die vernieude mens, al gaan die gevolge daarvan deur tot by die ewige lewe. Net soos in die natuurlike lewe die geboorte nie in 'n oomblik van tyd plaasvind nie, maar 'n proses is wat stadia deurloop, so kan dit by die wedergeboorte ook die geval wees - terwyl die verwekking bepalend is vir die geboorte en die hele lewe.

Die vraag kom egter op of ons nie in 'n ander rigting moet gaan soek indien Jesus se woorde in Joh. 3 nie vir almal (absoluut, eksklusief) verstaan moet word nie? Indien dit wel absoluut bedoel is, skyn dit asof daar geen ander keuse is as om te onderskei tussen weder-verwekking en wedergehoorte nie (vgl. punt e. onder). Dog as Joh. 3 alleen vir mense soos Nikodemus -- dus volwassenes - geld, dan lê die oplossing miskien in 'n ander rigting. Dan gaan ons nie probeer om te onderskei tussen die eerste hegin en die verdere ontwikkeling, God se hegin en daarna menslike medewerking nie. Dan sien ons die wedergeboorte as God se werk, God die H. Gees se wonderlike inwerking waardeur die mens wedergebore word, sodat die mens self ook wil en werk (vgl. DLR. III en IV.12: En dan word die wil wat nou vernuut is, nie alleen deur God gedrywe en beweeg nie maar, omdat dit deur God beweeg word, werk dit ook self). Die volheid van die nuwe lewe kan as wedergeboorte aitngedui word, en die mens word self gewaar en andere gewaar dit ook dat die Gees in hom gewerk het en nog werk. Teenoor Nikodemus stel Jesus dus duidelik dat hy met die leer nie die koninkryk sal bereik nie, omdat daar 'n breuk in sy lewe moet kom en lewensvernuwing moet plaasvind. Dat God die vernuwing bewerk, staan vas. maar Jesus sê nie op 
watter wyse of met welke middele dit geskied nie. Die Gees werk en die mens bemerk die wind-stote van die Gees in homself. Oor die wyse van God se werking moet ander Skrifgedeeltes ons inlig.

Alleen moet hierby nog gelees word 1 Petrus $1: 3:$ :Geseënd is die God en Vader van onse Here Jesus Christus wat na sy grote barmhartigheid ons die wedergeboorte geskenk het tot 'n lewende hoop deur die opstanding van Jesus Christus uit die dode". Dit is duidelik dat die opwekking van Christus uit die dode - en 1 Petrus 3 : 18 sê Christus is lewend gemaak deur die Gees - die onmisbare voorvereiste en noodsaaklike objektiewe grond is van die wedergeboorte van enige mens ivgl. ook IV.a).

\section{c. Wat is die Woord?}

Oor die verskillende betekenisse wat woord in die H. Skrif het, hoef ons nou nie te spreek nie (vgl. I.a; ook V, veral d.), maar ons bepaal ons by woord in sy verband met wedergeboorte.

Die Bybel spreek van die Seun as die Woord (Logos) van God. Deur Hom het alles ontstaan (Joh. 1 : 3). Daarom word $\mathrm{Hy}$ in die Dogmatiek Skeppingsmiddelaar genoem. Maar die Woord het vlees geword (Joh. 1 : 14). So is die Seun ook Verlossingsmiddelaar, deur Wie God sy skepping herstel. As Middelaar het Hy met sy versoeningswerk die mens uit die bande van sonde en dood verlos. Nou is dit verder treffend dat Hebr. 1 : lv. sê: „Nadat God baiekeer en op baie maniere in die ou tyd gespreek het tot die vaders deur die profete, het $\mathrm{Hy}$ in hierdie laaste dae tot ons gespreek deur die Seun, ... deur wie Hy ook dic wêreld gemaak het". Die lewe, werk en woorde van Jesus is dus spreke van God in die wêreld - en daarna moet geluister word.

Nou is dit verder so dat Christus se versoeningsarbeid 'n enige en eenmalige werk is (Hebr. $9: 26$ ), met betekenis vir alle tye en alle gelowiges. Daarom begryp ons goed as Petrus verklaar dat die wedergcboorte geskenk is deur die opstanding van Christus. Dáárdie feit is die realiteitsbasis en objektiewe grond van die verlossing van elke uitverkorene van God. Terwyl Christus se werk nooit herhaal kan word nie, moet die betekenis daarvan by elke verloste tuisgebring word. God se spreke deur die Seun moet deur elkeen wat verlos word, gehoor en aanvaar word. Dit kan alleen deur die H. Gees, ook genoem die Gees van Christus, gedoen word. Maar die middel waardeur God die H. Gees dit doen is die Woord.

Die Gereformeerde Teologie het steeds afgewys die opvatting asof die Woord van God in die Bybel is. Nee, die Bybel is Gods Woord. Oor hierdie hele saak is dit onnodig om uitvoerig te spreek. Tekste wat duidelik hieroor getuig, is o.a. 2 Tim. 3 : 16; 2 Petr. 1 : 19ev.; Rom. 15 : 4. Vergelyk hierby nog Rom. $13: 11$ : „Want daar is geskrywe: So waaragtig as Ek leef, sê die Here, voor My sal elke knie buig". Let op die indentifikasie van "geskrywe" en die „Here wat spreek" - vgl. 
ook Rom. 12 : 19; 1 Kor. 14 : 21; 2 Kor. 6 : 16ev.; Hebr. 8 : 8v. Insiggewend is hierby Hebr. 10 : 15v., waar sprake is van getuienis van die H. Gees, en God wat gesê het ${ }^{62}$ ) — vgl. ook Hebr. 3 : 7. Dit is verder so (vgl. V.d.) ${ }^{63}$ ) dat woord gelyk is aan „boodskap van Christus" (vgl. 1 Tim. 1 : 15).

In verband met die wedergeboorte moet woord dus verstaan word as die prediking van die Evangelie, wat tot mense kom. Dit oortuig van sonde en verlossing, omdat dit die boodskap van die Verlosser Jesus Christus is. Natuurlik werk die woord nie ,an sich" nie, maar dit is werksaam omdat dit die van God gespreekte en gehandelde Woord is, en omdat dit genade, redding en lewe is.

d. Woord en wedergeboorte.

Ons lees hierby twee uitsprake van die Skrif. Jakobus $1: 21$ sê: "... ontvang met sagmoedigheid die ingeplante woord wat in staat is om julle siele te red." En 1 Petrus 1 : 23ev. getuig: „... julle is wedergebore ... deur die lewende woord van God ... En dit is die woord wat aan julle verkondig is". Die wederbaring geskied deur die Woord van God, die verkondigde Woord. Ons moet onthou dat Joh. 3 oor die wedergeboorte gesê het dat die Gees vrymagtig werk, soos die wind - en dat ons van die wind alleen weet as dit teen of deur iets waai, en sy gevolge gewaar word. Die wedergeboorte self kan ons nie sien of meet nie, maar sy gevolge is duidelik en sigbaar - en oortuigend. So verstaan ons dan ook Jak. 1 : 21, waar sprake is van die ontvang: van die woord -- terwyl ons voortgebring is deur die woord van waarheid (Jak. 1 : 18). Hier is dus die bewuste en blye aanneem van die Woord - en dan word meteen duidelik dat die wind van die Gees deur die Woord gewerk het. Mooi sê Paulus in 1 Thess. 2 : 13: „Daarom dank ons God... dat, toe julle die woord van God ontvang het, wat deur ons verkondig is, julle dit aangeneem het nie as die woord van mense nie, maar, soos dit waarlik is, as die woord van God wat ook werk in julle wat glo".

Daar is dus geen beswaar teen bewuste aanvaarding van die Woord en menslike medewerking - natuurlik deur die $\mathrm{H}$. Gees - by die wedergeboorte nie, soos wat hulle graag wil volhou wat die wedergeboorte nie sien as die blote begin van die vernuwing van die mens nie. Die eenheid van God en die mens se werk word dus gehandhaaf. Ons glo ook dat ons hiermee nog steeds in lyn is met ons belydenisskrif, die DLR. in III en IV.17. Nadat oor die natuurlike lewe gespreek is, wat deur Gods almag voortgebring is en onderhou word en tog die gebruik van middele toelaal, word verder gesê: „Net so sluit ook die voormelde bowenatuurlike werking van God, waardeur Hy ons wederbaar, volstrek nie uit nie en dit stoot volstrek nie omver die gebruik van die Evangelie wat die wyse God as 'n saad van die wedergeboorte en 'n spys vir die siel verordineer het nie". Let op die onderskeiding van bowenatuurlike werking en die gebruik van die Evangelie, en by laasgenoemde die onderskeiding tussen saad en voedsel vir die siel. Ons weet van ons wederge- 
hoorte dus alleen deur die antwoord op God se Woord, deur die vrugte ran die Gees, wat deur en in die Woord werk, in ons eie lewe. En al kan ons die aard van hierdie werking in hierdie lewe nie verstaan nie, is dit vir ons 'n gerusstelling dat ons weet en gevoel dat ons deur hierdie genade van God met die hart glo en ons Saligmaker liefhet (vgl. DLR. III en IV. 13). By alles moet ons onthou dat daar geen ontstaan of voortgang van die nuwe geestelike lewe moontlik is sonder die Heilige Gees van God nie.

\section{e. Wedergeboorte en vroeg-sterwende kinders.}

As sodanig het die vraagstuk van vroeg-sterwende kinders nie met ons onderwerp te doen nie, omdat klein kindertjies nog nie bewustelik die Woord kan hoor nie. Maar juis omdat hulle wel met die saak van die wedergeboorte te doen sal hê, is dit tog nodig dat ons hieraan aandag sal skenk. En die verskillende interpretasie van die vereiste wat Jesus volgens Joh. 3 stel, sal hier beslis sy invloed laat geld.

As ons die eis van Joh. 3 in absolute sin moet neem, dan geld selfs vir die kleinste kindjie die voorwaarde van die wedergeboorte om in Gods koninkryk te kom. Aangesien die Gees van God aan geen leeftyd gebonde is om te kan werk nie, omdat Hy vrymagtig in Sy optrede is, spreek dit vanself dat die H. Gees ook in die klein kindjie kan werk wonderbaarlik en onnaspeurlik. Die gedagte van weder-verwekking, as beginsel van die nuwe lewe, wat deur direkte inwerking van die Gees bewerk is, kan ons dan in die regte rigting lei. Hierdeur word die mistieke hand met Christus aangelê, en dit is noodsaaklik vir verlossing. Christus het opgestaan tot redding van die nuwe mensheid en alleen hulle wat met Hom verbind is, wat lid is van Sy liggaam, verkry die heil. Vanselfsprekend moet hierby egter met die genadeverbond van God rekening gehou word, anders sou die waarheid van die weder-verwekking kan of moet geld vir elke of enige kind. Dit is juis waarheen ons DLR. ook wys as gesê word dat die kinders van die gelowiges heilig is kragtens die genadeverbond waarin hulle saam met hulle ouers opgeneem is (I.17). Dit gaan dus hier om die kinders van die verbond.

Ons moet daarmee rekening hou ${ }^{64}$ ) dat die Skrif duidelik spreek oor die indiwiduele, persoonlike verlossing (vgl. Luk. 15:4, 7,10 ; Joh. $10: 3$; Openb. $20: 11-15)$, maar an die ander kant word die gelowige(s) nie gesien as 'n geïsoleerde persoonlikheid of siel, of as los indiwidue nie. Let bv. op die betekenis van die geslagsregisters. God werk tog nie bloot met indiwidue nie maar nok met geslagte, volke, nasies (vgl. Openb. $21: 24,26 ; 22: 2$ ). In die gelowiges word geslagte en nasies gered, en die volk van God is vergader nie net uit die mensheid nie, maar dit is die (nuwe) mensheid. Die kerk is tog ook nie 'n samegroepering van los indiwidue ('n menigte) nie, maar 'n gemeente of liggaam of organisme. God se uitverkiesing gaan - volgens die open. 
baring in die Skrif - nie atomisties-indiwidueel te werk nie, maar loop in die lyn van die geslagte. Ons ken tog die bekende beeld: die rivier van die uitverkiesing loop in die bedding van die verbond. So kan miskien gesê word dat die weder-verwekking plaasvind in die skoot van die kerk, die moeder van die gelowiges.

In hierdie aangeduide rigting sal ons die weergawe van die verloop van sake i.v.m. die kindertjies moet soek indien ons Joh. 3 se eis absoluut en eksklusief moet vertolk. Dit kan egter nie ontken word dat dit wel enigsins kunsmatig of geforseerd voorkom nie. Dit lyk amper te veel na 'n rasionalisering van die misterieuse werking van God. Daarom moet ons tog ook let op die moontlikheid van die ander interpretasie, nl. dat Joh. 3 nié spreek ook oor die klein kindertjies nie. Hierby kan ons egter geensins wegbeweeg van die verbond af nie, omdat dit alleen die waarborg is dat ons op die regte spoor bly.

Laat ons rigting soek by 'n uitspraak van Calvyn. ${ }^{65}$ ) Hy sê dat I Petrus I : 23 allcen oor die gclowiges spreek wat deur dic prediking van die Woord onderwys is (dus volwassenes) en dat vir diesulkes die Woord van die Here die enigste saad is van die geestelike wedergeboorte. Daarmee word egter nie ontken dat klein kinders wel deur Gods krag wedergebore kan word nie. Want Gods krag staan Hom ewe geredelik ten diens as wat dit vir ons onbegryplik en bewonderenswaardig is. Bowendien sou dit nie versigtig genoeg wees om aan die Here die vermoë te ontsê om Hom aan die kinders op cen of ander wyse kenbaar te maak nie. Dat die geloof uil die gehoor is, heskryf God se gewone beleid en beheer, maar dit stel aan Hom geensins 'n voortdurende reël sodat $\mathrm{Hy}$ geen ander manier sou kan gebruik nie. En ongetwy feld het $\mathrm{Hy}$ 'n ander manier gebruik in dic rocping van vcle wat $\mathrm{Hy}$ alleen deur die innerlike verligting van die Gees. sonder tussenkoms van die prediking, met ware kennis oor Hom hegiftig het.

Ons bemerk dus dat Calvyn wel die moontlikheid wil ooplaat dat dic kinders van die verbond deur God op 'n besondere wyse met die genade van die lewe begiftig word. Mens besef die gevare wat hierin skuil, maar as ons binne die verband van die verbond bly, kan ons nie so maklik op verkeerde paaie afdwaal nie. Die H. Skrif spreek tog duidelik oor die geheilig-wees van die kinders van die gelowiges. En as 'n kind nou vrocg te sterwe kom, voordat hy die Woord bewustelik kon hoor of ook sclfs willens-en-wetens die vereistes van die verbond kon oortree het -... bv. deur ongehoorsaam an dic roepstem van die Woord te wees - dan mag die ouers nie twyfel aan die saligheid van hul kinders nie. Johannes 3 en ander Skriftekste (hv. Rom 10:17;1 Petrus 1 : 23) moet dus gelees word as verwysende na volwassenes. Maar God se verbond reken met en werk met geslagte. En niemand het dic bevregdheid om aan God die mag en die reg te ontsê om dic kinders dic nuwe lewe te skenk nie, al son dit selfs wees hy die dood of die intrede in die enige 
heerlikheid. Die wedergeboorte van die mens vind tog sy kompleetheid nie in hierdie lewe nie, maar eers met of na die dood, in die hereniging van liggaam en siel en die beërwing van die nuwe aarde. Elke gelowige se dood het dus nog betekenis vir sy wedergeboorte. Daarom kan God beslis hierdie vernuwing aan die klein kindjie skenk in die oomblik van sy dood. Calvyn sê duidelik: „Niemand van die uitverkorenes word uit die teenwoordige lewe opgeroep nie, as hy nie eers geheilig en weder. gebore word deur die Gees van God nie. Daar is ook geen gevaar daarin geleë om te sê dat die kinders reeds 'n deel ontvang het van die genade waarvan hulle die volle oorvloed eers 'n rukkie later sal geniet nie. Sommige mense word tog eers van hulle onwetendheid verlos wanneer Hy hulle trek uit die kerker van die vlees, al sou hulle nic begaaf wees met dieselfde geloof as ons nie of al sou hulle kennis nie gelyk aan die geloof wees nie. As God wil, kan $\mathrm{Hy}$ tog vir hulle wat $\mathrm{Hy}$ met die volle glans van sy lig sal bestraal, reeds in hierdie lewe met 'n klein vonkie daarvan bestraal".66)

Daarom glo ons dat die kinders van gelowiges wat vroeg sterwe wel wedergebore word deur die Gees van God, sonder die geprediktc Woord. Nooit mag die band aan Christus en sy opstanding egter deurgesny word nie. Maar juis hierdie band word deur die Gees aangelê.

Viljoenskroon.

D. Kempif.

\section{AANTEKENINGS:}

1) Chr. Encyclopaedie oor Hoord.

2) Bavinck - Geref. Dogmatiek IV, p. 27

3) A. D. R. Polman - Onze Nederl. Geloofsbelijdenis III, p. 112ev.

4) A. Kuyper - Het werk van de H. Geest (1927), p. 404ev.

5) C. Vonk - Huisbezoek naar Gods geboden (Kok, s.j.).

6) Id., p. 92ev.

7) Greydanus - Kommentaar (Bottenburg), p. 38.

8) Id., p. 80v.

9) Grosheide - Korte Verklaring, p. 24v.; Konınt. (Bottenburg), p. 442v.

10) Kuyper - E Voto II, p. 420v.

11) Id. - Loc. de Providentia, p. 74.

12) I1. - Loc. de Salute, p. 75.

13) Id. - Loc. de Deo, I, p. $218 v$.

14) Id., p. 263.

15) Il. - Gemeene Gratie II, p. 214v.

16) Id. - Werk van de H. Geest II, p. 403v.

17) Irl., p. 407.

18) Bavinck - Dognatiek IV, p. 22v.

19) Id., p. 6lev.

20) Vonk - a.w., p. 76.

21) Id., p. $41 \mathrm{v}$.

22) Id., p. 55v.

23) Kittel - Theol. Wörterbuch z. N.T. IV.

24) Id., p. 95

25) Id., p. 97. 
26) Id., p. 117.

27) Id., p. 119v.

28) Id., p. 120 v.

29) Bavinck -- Dogmatiek IV, p. 57.

30) Kuyper - Werk van de H. Geest II, p. 407v. (vgl. 382v.).

31) Id. - Gemeene Gratie II, p. 216.

32) Id. - E Voto II, p. $424 \mathrm{v}$.

33) Id. - Werk van de II. Geest II, p. 399ev.

34) Id. - Gemeene Gratie II, p. 213.

35) Id. - Loc. de Salute, p. 75.

36) Vgl. id. - Loc. de Deo l, p. 218v.

37) Id. - Werk van de H. Geest II, p. 479ev.

38) Id., p. 396.

39) IJ., p. 4]0ev.; 423v.

40) Vonk - a.w., p. 4lv. en 59v.

41) Bavinck - Dogmatiek IV, p. 42v.

42) Id. - III, p. 669ev.

43) Id. - IV. p. 58v.

44) Id., p. 27.

45) Id., p. 63

46) Idl., p. 64.

47) Id., p. 64ev.

48) Id., p. 72ev.

49) Kuyper - Gem. Gratie II, p. 207ev.; E Voto II, p. 424v.; W. v. d. H. G. II. p. $396 \mathrm{cv}$.

50) Id. - Werk van de H. Geest II, p. 423.

51) Vonk - a.w., p. 95ev.

52) Bavinck -- Dogmatiek IV, p. 33.

53) Id., p. 59ev.

54) D. J. de Groot - De Wedergeboorte (Kok, 1952), p. 132 en 211.

55) Id., p. $212 \mathrm{v}$.

56) Id., p. 132,212

57) Id., p. 21 lev.

58) Calvyn - Institusie IV.16, 18 en 19 (by De Groot, a.w. p. 257)

59) Grosheide - Kommentaar Johannes (Bottenburg) I, p. 206.

60) Id., p. 90: ,Ook gennan, toch eigenlijk de daad van den man...." Vergelvk Greydanus (by De Groot - a.w., p. 193): Vir wedergeboorte wort in die N.T. nie siktein gehruik nie, maar gennan of anagennan, wat dir werkeaamheid van die man aandui, al word dit soms - in verswakking of veralgemening van die vrou gehruik.

61) Vgl. Grosheide - Kommt. Joh. (Bottenhurg) oor Joh. 3.

62) Vgl. Grosheide - Kommt. llebrcêrs (Bottenburg), p. 281.

63) V $\mathrm{gl}$. nolas 24) tol 28).

64) W. J. Snyman in Handelinge van die Algemene Sinode van die Geref. Kerk in S.A. 196], p. 82v.

Met dank erken ons ook die hulp t.o.v. eksegetiese gefeeltes wat verkry is deur gesprekke met prof. Snyman.

65) Calvyn - Institusic IV. 16, 18 en 19 (vgl. 58).

66) Id. 